\title{
Assessment of Land Use in A Conservation Unit in the Brazilian Pantanal by Remote Sensing
}

\author{
${ }^{1}$ Victor Hugo de Morais Danelichen, ${ }^{2}$ Osvaldo Alves Pereira, ${ }^{3}$ Jonathan Willian Zangeski Novais ${ }^{4}$ Marcelo \\ Sacardi Biudes, ${ }^{5}$ José de Souza Nogueira and ${ }^{6}$ Antonio Ramos Correia. \\ ${ }^{1,2,3}$ Programa de Pós-graduação em Ciências Ambientais - Universidade de Cuiabá - UNIC, St. Barão de Melgaço, 222 - Porto, Cuiabá - MT, Brazil \\ 4,5,6 Programa de Pós-graduação em Física Ambiental - Universidade Federal de Mato Grosso - UFMT, Av. Fernando Corrêa da Costa, 2367. Cidade Universitária, \\ Bloco de Física Ambiental, Cuiabá - MT, Brazil
}

Correspondence Author: Victor Hugo de Morais Danelichen, Programa de Pós-graduação em Ciências Ambientais - Universidade de Cuiabá - UNIC. Address: St. Barão de Melgaço, 222 - Porto, Cuiabá - MT, Brazil, Zip code: 78005-300, Phone: 5565 3363-1729.

E-mail: danelichen@ fisica.ufmt.br

Received date: 18 May 2019, Accepted date: 26 June 2019, Online date: 29 June 2019

Copyright: () 2019 Victor Hugo de Morais Danelichen et al, This is an open-access article distributed under the terms of the Creative Commons Attribution License, which permits unrestricted use, distribution, and reproduction in any medium, provided the original author and source are credited.

\begin{abstract}
Among other biomes found in the Brazilian territory, the Pantanal has been characterized by the smallest percentage of protected areas in the country. To protect a portion of the Brazilian Pantanal biome, the Private Natural Heritage Reserve (RPPN SESC Pantanal) was created in 1997. In 2002, the RPPN was recognized as a "Ramsar site" by the Convention on Wetlands of International Importance. The vegetation found in the RPPN presents rapid and strong transitions, which influence the dynamics between the surface and the atmosphere of this ecosystem. Works that were carried out in the last years in the reserve were produced with data of meteorological towers and with little time of monitoring, that only provide temporal and local analysis. Therefore, the aim of this work was to evaluate the changes of land use and occupation in a conservation unit in the Brazilian Pantanal using remote sensing in a period after its creation. The study was carried out in the Private Reservation of Natural Patrimony - RPPN SESC Pantanal distant $160 \mathrm{~km}$ from Cuiabá-MT, Brazil. Images of the surface classification MODIS sensor product and the of the TRMM satellite product for the rainfall regime were used in the years $\mathbf{2 0 0 0}$ to 2012. Our results demonstrated a progressive increase in forest class and attenuation in the classes less vegetated. It was observed in the last year that the forest class presented an increase superior to $15.6 \%$, as opposed to the shrub and grassy classes, which presented a decrease of $6.6 \%$ and $9.1 \%$. The results also indicate that the MODIS product is a useful tool and has been shown to evaluate the conservation effect of a large area reserve in the Mato Grosso Pantanal. We also emphasize that the product MCD12Q1 can be used, except for some limitations in studies of the Pantanal biome, which are due to the use of classes of nomenclatures and ecosystems distinct from those that have been validated the product, its low spatial resolution restricting to studies of smaller areas in this biome.
\end{abstract}

Keywords: Pantanal, orbital sensors, land cover.

\section{INTRODUCTION}

Among other biomes found in the Brazilian territory, the Pantanal has been characterized by the smallest percentage of protected areas in the country (4\%, belonging to the states of Mato Grosso and Mato Grosso do Sul), behind only the Pampa biomes (3.5\%) and (1.5\%), where the Amazon biome corresponds to $26.2 \%$, Cerrado to $7.9 \%$, Atlantic Forest to $7.8 \%$ and Caatinga to 7.3\% (Gurgel et al., 2009, Vigano et al., 2018). Floodplain areas are among the most fragile and sensitive ecosystems on the planet, and the Mato Grosso Pantanal is one of the greatest examples, with wide hydrological complexity, generating in scientists the need to know better the dynamics of hydrological cycles and their influence on local vegetation (Novais et al., 2018). To preserve a portion of the Pantanal, the Private Natural Heritage Reserve (RPPN, from the original Portuguese) SESC Pantanal (Social Service of Commerce) was created in 1997. The RPPN is in the northeast of the Pantanal of Mato Grosso and occupies an area of $1076 \mathrm{~km}^{2}$. In 2002, the RPPN SESC Pantanal was recognized as a "Ramsar site", a term designated as a Priority Area for Biodiversity Conservation, by the Convention on Wetlands of International Importance, known as the Ramsar Convention, for national actions and cooperation between countries which aims at national actions and cooperation among countries with the objective of promoting the conservation and rational use of wetlands in the world (Cordeiro, 2002; Brandão et al., 2011). 
The vegetation found in the RPPN SESC Pantanal presents fast and strong transitions, which effectively influence the dynamics of energy flows and evapotranspirative processes between the surface and the atmosphere of this ecosystem (Cordeiro, 2002; Danelichen et al., 2016). In addition, works that were carried out in the last years in the reserve were produced with data of meteorological towers and with little time of monitoring (less than 5 years), that only provide temporal and local analysis of the microclimatic variables, not allowing a spatial vision of the dynamic vegetation (Cordeiro et al., 2002; Hofmann et al., 2010; Aquino et al., 2017).

To contemplate the variations in the time-space plan of the Pantanal, studies on the dynamics of land use change and occupation are of great importance (Leite and Brito, 2012; Miranda et al., 2018). The monitoring of the dynamics of the biophysical parameters of the terrestrial surface allows to diagnose natural and anthropic alterations in the landscape of an ecosystem (Cunha et al., 2012). The computation of these parameters, such as albedo, surface temperature and vegetation indices, on a regional scale, would represent a great expenditure of material and human resources, since the construction of maps of each parameter are indicators of the health of that biome (Oliveira et al., 2012; Novais et al., 2016).

Thus, remote sensing allows the mapping of leaf and biomass of the vegetation through these biodiversity indicators (Barbosa et al., 2012, Rocchini, 2013, Jiang et al., 2013), contributing to obtain reliable information on the species in space and time, if it guarantees an entire space coverage in a short period of time (Feilhauer and Schmidtlein, 2009; Rocchini and Neteler, 2012). Since the launch of the first Landsat satellite in the NASA program in 1972, remote sensing has been one of the most powerful tools for directly and indirectly detecting the properties of terrestrial surface biodiversity (Rocchini, 2013). With the increase in the number of sensors with high spatial and temporal resolution, the properties of plant biomass and vegetation phenology that are "invisible" in the field can be revealed (Jiang et al., 2013).

The Moderate Resolution Imaging Spectroradiometer (MODIS) is one of the most advanced sensors for monitoring largescale changes in the biosphere in remote sensing. In addition, the MODIS system provides information about the behavior of the Earth's surface using high-performance algorithms (Senna et al., 2007; Andrade et al., 2017).

In this context, studies involving remote sensing techniques were carried out aiming to quantify and characterize the different vegetation classes within the Mato Grosso Pantanal. Among them some stand out for the different methodologies and periods.

Abdon et al. (1998) studying the Nhecolândia sub-region in the Brazilian Pantanal with an image of the Landsat satellite (drought of 1990) provided important information on the distinctions of areas of agricultural management and Phytophysiognomies found there. Silva et al. (2000) using aerial images of a Cessna 206 airplane at the end of the dry season of 1991 identified 16 classes within the Mato Grosso Pantanal. Fantin-Cruz et al. (2010) studying the Pantanal flood regime in mesoscale quantified and characterized the different Phyto physiognomic units by means of supervised classification of images of the satellite CBERS 2B sensor CCD in the year 2007. Ravaglia et al. (2011) studying the sub-regions of Nhecolândia and Poconé, used the methodology adopted by Rodela et al. (2007) with images from 1999 and 2005 of the satellite Landsat 5, the authors find 10 classes, with predominance of seasonally flooded savanna areas, evidencing the dynamics of these areas with shrub species adapted to the flood cycle. Peres et al. (2016) using different period data (2000 and 2015) of the normalized difference vegetation index (NDVI) using the MODIS sensor (product MOD13Q1) in the Mato Grosso Pantanal demonstrated that the native vegetation class was replaced by areas of pastures. These studies show alarming results regarding the preservation of the Pantanal biome in Brazil, and the need for precise analyzes with larger numbers of observations and data collection.

Therefore, the objective of this work is to evaluate the changes in land use and occupation in a conservation unit in the Brazilian Pantanal using remote sensing in a period after its creation.

\section{MATERIAL AND METHODS}

\subsection{Study area and outline of the study}

The study was carried out in the Private Natural Heritage Reserve - RPPN SESC Pantanal, created in 1997, the RPPN is in the municipality of Barão de Melgaço - MT, distant $160 \mathrm{~km}$ from Cuiabá-MT, Brazil, with coordinates of 16³9'50 "S, $56^{\circ} 47^{\prime} 50^{\prime \prime} \mathrm{W}$ and altitude of $120 \mathrm{~m}$ (Figure 1). The topography of the floodplain is practically flat, causing flooding, 1-2 $\mathrm{m}$ (Nunes Da Cunha and Junk, 2004). The soil is classified as GLEISSOLO HÁPLICO Ta Dystrophic (Machado et al., 2015). The annual precipitation and temperature of the region is, in average, $1,400 \mathrm{~mm}$ and $26,1^{\circ} \mathrm{C}$ with a pronounced dry season that extends from May to September (Biudes et al., 2012). 
Fig. 1: RPPN Sesc Pantanal location.

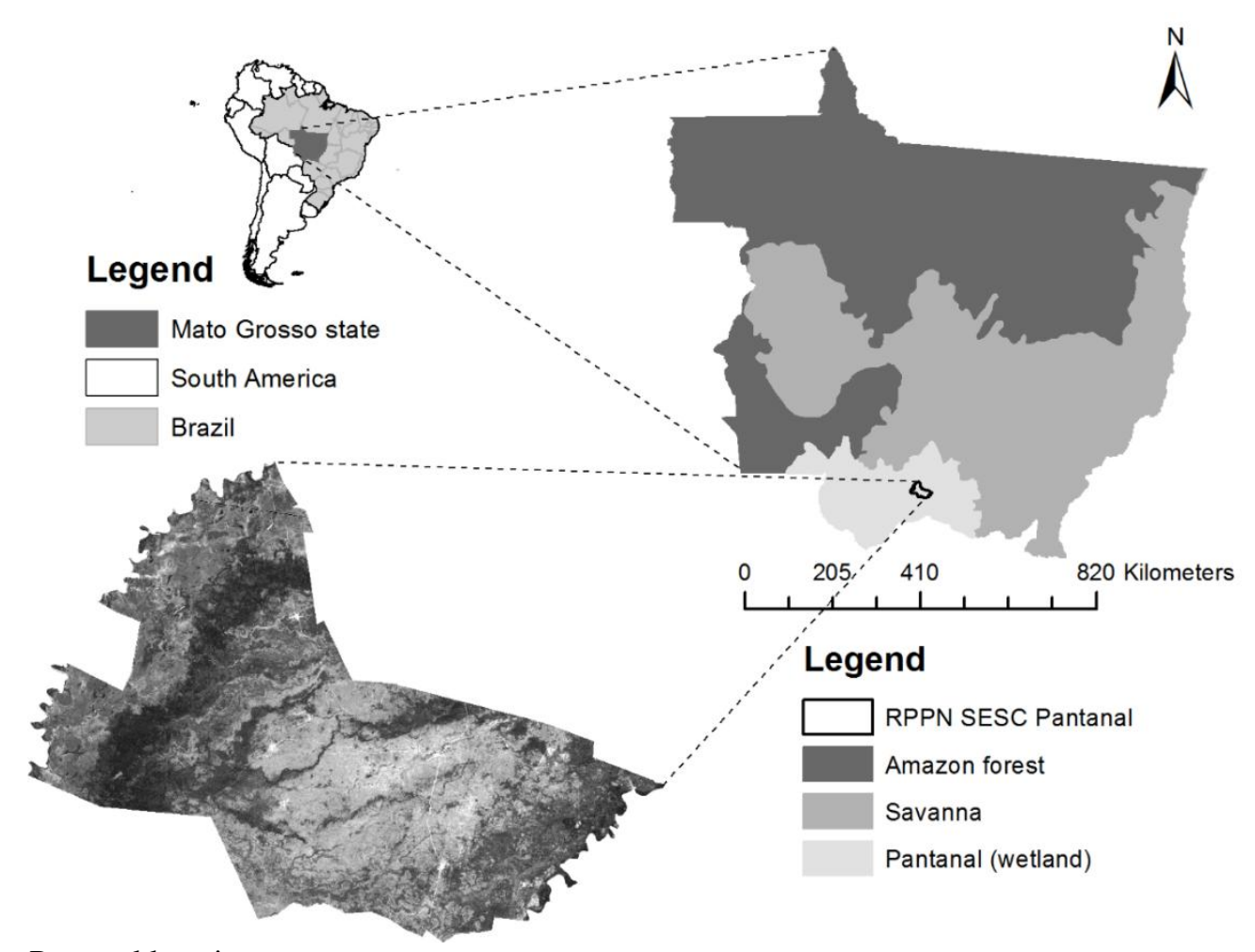

\subsection{Orbital data}

The spatial distribution of the types of surface cover classes in the SESC Pantanal RPPN region was obtained from the product MCD12Q1 through the MODIS sensor. It contains five types of classification that describe the properties of surface coverage derived from observations of the MODIS sensor on board the AQUA and TERRA satellites during a year. The surface coverage schema identifies classes defined by the International Geosphere-Biosphere Programme (IGBP), which includes 11 natural vegetation classes, 3 classes of urbanized lots and 3 classes of vegetated ground, of which only 10 belong to the reserve (Table 1). The product supplies global maps of land cover at annual time steps and $500 \mathrm{~m}$ spatial resolution for 2001-2012.

The product preprocessing MODIS was held at python language using the framework Pythonwin with the goal of making them into the Hierarchical Data Format (HDF) format to GEOTIFF, to change the system from sinusoidal projection Universal Transverse Mercator (UTM) to World Geodetic System 84 (WGS 84) and to cut the shape of RPPN SESC Pantanal. The download of the images was done at the website (https://lpdaac.usgs.gov/data_access/data_pool).

The choices of the MCD12Q1 product classification types were based on the work of Cordeiro et al. (2002) that classified the RPPN SESC Pantanal, in view of the greater compatibility of corresponding classes with those found in the Pantanal (Table 1).

To evaluate vegetation dynamics in conjunction with the rainfall regimes of the RPPN SESC Pantanal, precipitation data were obtained by the TRMM (Tropical Rainfall Measuring Mission) sensor, released by NASA in 1997, made available by GES DISC (Distributed Active Archive System) in the website (https://disc.sci.gsfc.nasa.gov/), TRMM Online Visualization and Analysis System. The TRMM pixel has a minimum area of approximately $0.25 \mathrm{~km}^{2}$, as the study area comprises 4 pixels of the radar, the average of these pixels was realized for the real estimate of the precipitation. Data from the 3B43 V6 product from 2000 to 2012 were used (Figure 2).

Table 1: Classification of land use and land cover by means of the MCD12Q1 product and its corresponding ones for study area.

\begin{tabular}{|c|c|c|}
\hline Classes Number & MCD12Q1 Classes & $\begin{array}{c}\text { RPPN } \\
\text { (equivalent classes) }\end{array}$ \\
\hline 0 & Water & Water \\
\hline 1 & Evergreen Needleleaf trees & Forest \\
\hline 2 & Evergreen Broadleaf trees & Forest \\
\hline 3 & Deciduous Needleleaf trees & Forest \\
\hline 4 & Deciduous Broadleaf trees & Forest \\
\hline 5 & Shrub & Shrub \\
\hline 6 & Grass & Grass \\
\hline 7 & Cereal crops & Cereal crops \\
\hline 8 & Broad-leaf crops & Forest \\
\hline 9 & Urban and built-up & Urban \\
\hline
\end{tabular}




\subsection{Statistical analysis}

For the evaluation and validation of the number of classes of product MOD12Q1, the Sturges rule (Sturges, 1926; Mendonça et al., 2019) was used with Excel program:

$$
k=1+3.33 \log N
$$

where $k$ corresponds to the classes number and $N$ corresponds to the number of elements in the series (pixels number). The amplitude of the class intervals was obtained by dividing the Total Amplitude of Variation by the number of classes, reaching a range of amplitude class (Table 2).

\section{RESULTS AND DISCUSSION}

Annual rainfall ranged from $1023.9 \mathrm{~mm}$ to $1665.1 \mathrm{~mm}$, with average rainfall of $1342.8 \mathrm{~mm}$ over the whole analyzed period, 12 years (Figure 2). During the analyzed period, which corresponds to the dates of the MODIS product images (MCD12Q1), the largest accumulation occurred in 2001 and lower in 2010 in the RPPN SESC Pantanal (Figure 2).

The accumulation recorded in the year 2001 may be related to the climatic conditions recorded this year. The year 2001 presented the highest Niño Ocean Index (NOI) in an interval of approximately 30 years in the state of Mato Grosso (Oliveira et al., 2015). As well as the minimum accumulated in 2010 should occur occurrence of the phenomenon La Niña (Ramos et al., 2015).

The accumulation recorded in the post-creation period (years after 1997) of the RPPN SESC Pantanal is possibly due to the El Niño phenomenon, which has a frequency of approximately seven years, culminating in the post-creation period. The probable cause of this phenomenon is its interference with rainfall, which is little or almost unknown, if it causes changes in the rainfall regime of the Central-West region of the country, since its "striking" consequences are to the north and south of Brazil (Melo, 2000). The accumulation in the period after the creation was related to the atmospheric conditions of October 2008, influenced by the end of the La Niña event (INPE/CPTEC, 2009).

Cardoso et al. (2010) analyzing 3 decades (1977 to 2006) of precipitation data collected in 12 rainy seasons in the Pantanal biome observed a significant spatial variation in the amount of rainfall and that during the period there was a gradual decrease in precipitated quantity of the 1977 from 1986 to the decade from 1997 to 2006 . This last decade coincides with the year of creation of the RPPN SESC Pantanal, which may justify the lower accumulations recorded in 2005 and mainly in reserve 2010 (Figure 2).

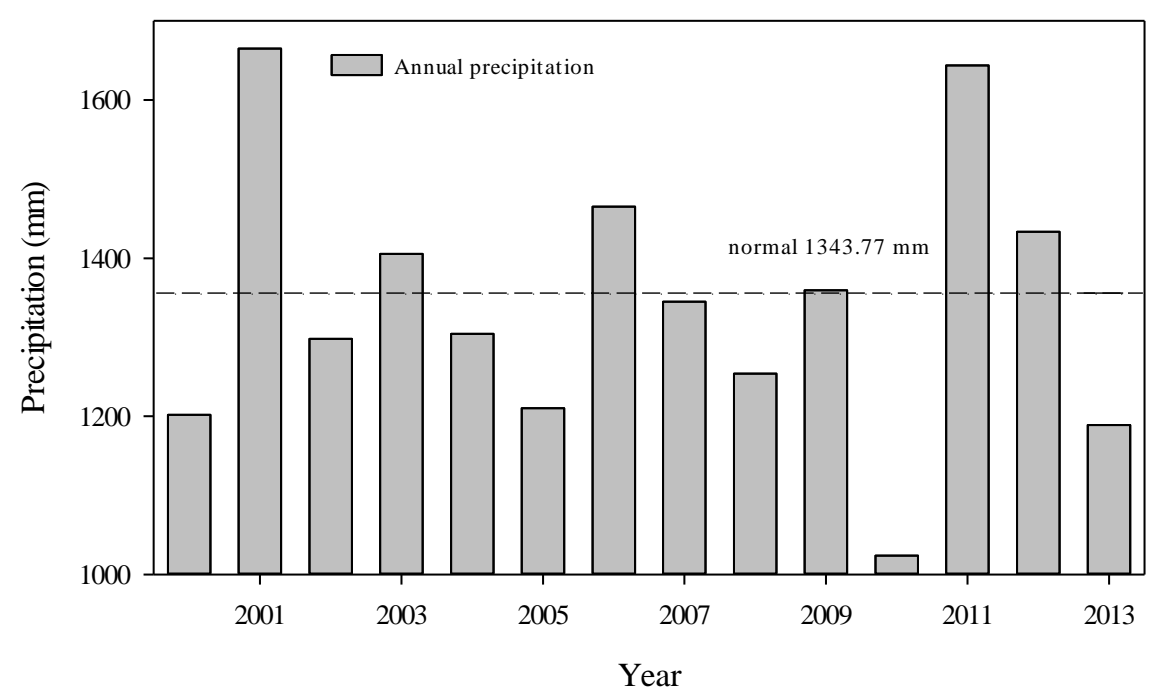

Fig. 2: Precipitation distribution estimated annually by the TRMM satellite of the RPPN SESC Pantanal.

In the analysis of the scenes, the forest class presented the highest occupancy in all years in the RPPN SESC Pantanal, approaching an average of $85.0 \%$ of area occupancy in relation to other classes during the entire study period, 2001 to 2012 (Figure 3). In the last analyzed year, 2012, the forest class reaches its maximum occupation of $95.0 \%$, while the shrub and grassy classes present occupancy of less than $4.0 \%$ for the same year (Figure 3). It is worth noting that in 2005 the forest class had a minimum occupancy of approximately $75.5 \%$ of the total area of the reserve, and the occupation of $20.2 \%$ of the grassland class (Figure 3 and 5). This higher occupation of the grassland class this year is possibly due to the lower annual accumulation of precipitation in the RPPN SESC Pantanal, there is also a decrease in the annual accumulation of the years 2001 to 2005 of approximately $454.9 \mathrm{~mm}$ (Figure 2). The average occupation of the grassy class for the whole analyzed period was approximately $11.5 \%$ of the total area of the reserve.

According to Hofmann et al. (2010) the highest vegetation density considered forest class in the RPPN SESC Pantanal is composed mainly of greater predominance of monodominant forest of Cambarazal (Vochysia divergens) and Mata Densa. When compared to the other formations, the Cambarazal is imposed by the average height of the canopy (approximately $28 \mathrm{~m}$ ), being the 
highest one registered inside the RPPN SESC Pantanal, whereas the Dense Forest is a densely forested formation and with great species richness, is presented as riparian and non-flooded forest on the São Lourenço River (Hofmann et al, 2010).

The shrub class presented its greatest occupation in 2001, being approximately $8.3 \%$ occupancy of the total area of the reserve (Figure 4 and 5). Among all the analyzed period, the shrub class presented an average of $3.4 \%$ of the total area of the reserve (Figure 3 and 4). The largest occupation of this class in the year 2001 is possibly linked to the largest accumulation of precipitation during the whole period for this year (Figure 2). This maximum of occupation given by the shrub class may also be linked to the newly formed reserve that was institutionalized in 1997 (Cordeiro et al., 2002).

According to Cordeiro (2004) dense shrubby vegetation is a plant formation located on the banks of the Cuiabá River in the western portion of the RPPN SESC Pantanal (Figure 1) characterized by being in a zone of lower altimetry under the influence of the flooding regime during the wet season, remaining wet until the dry season in the Pantanal (August).
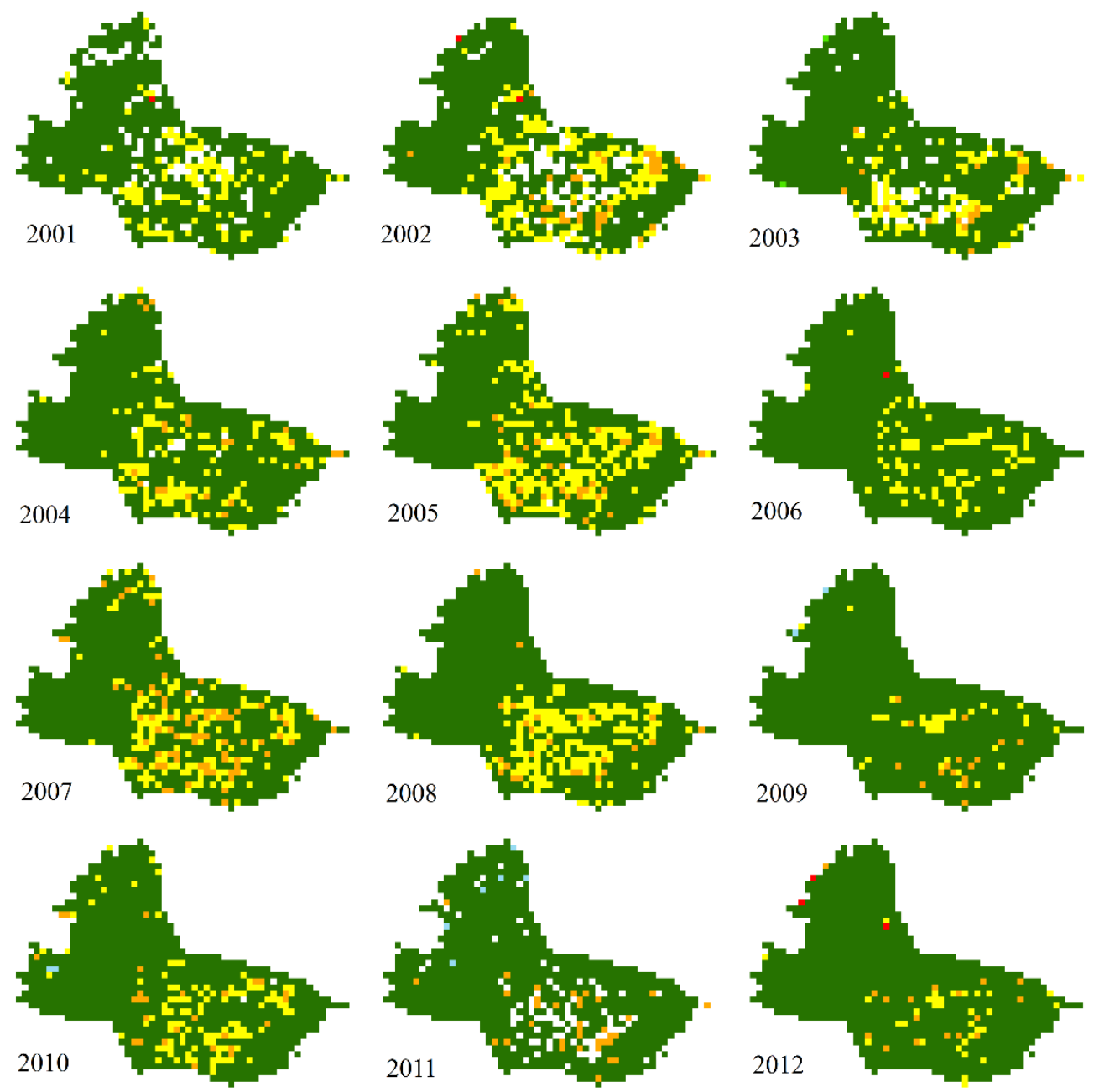

\section{Use and land cover}
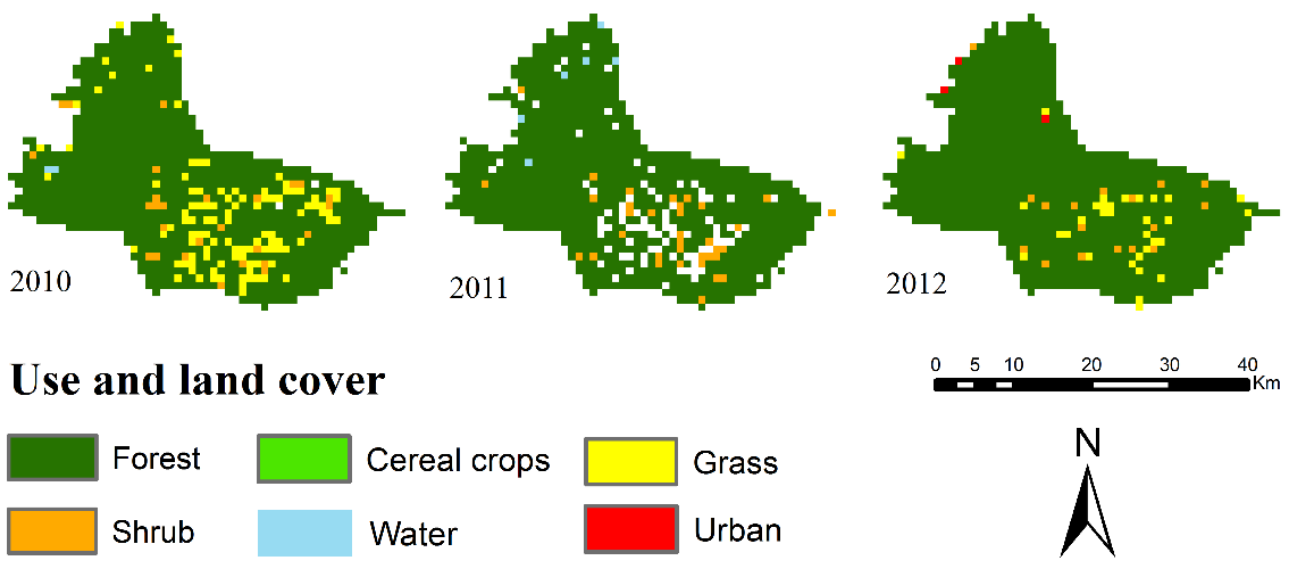

Fig. 3: Soil cover of the RPPN SESC Pantanal (2001-2012). 
Citation: Victor Hugo de Morais Danelichen, et al., Assessment of Land Use in A Conservation Unit in the Brazilian Pantanal by Remote Sensing. Australian Journal of Basic and Applied Sciences, 13(6): 141-150. DOI: 10.22587/ajbas.2019.13.6.16

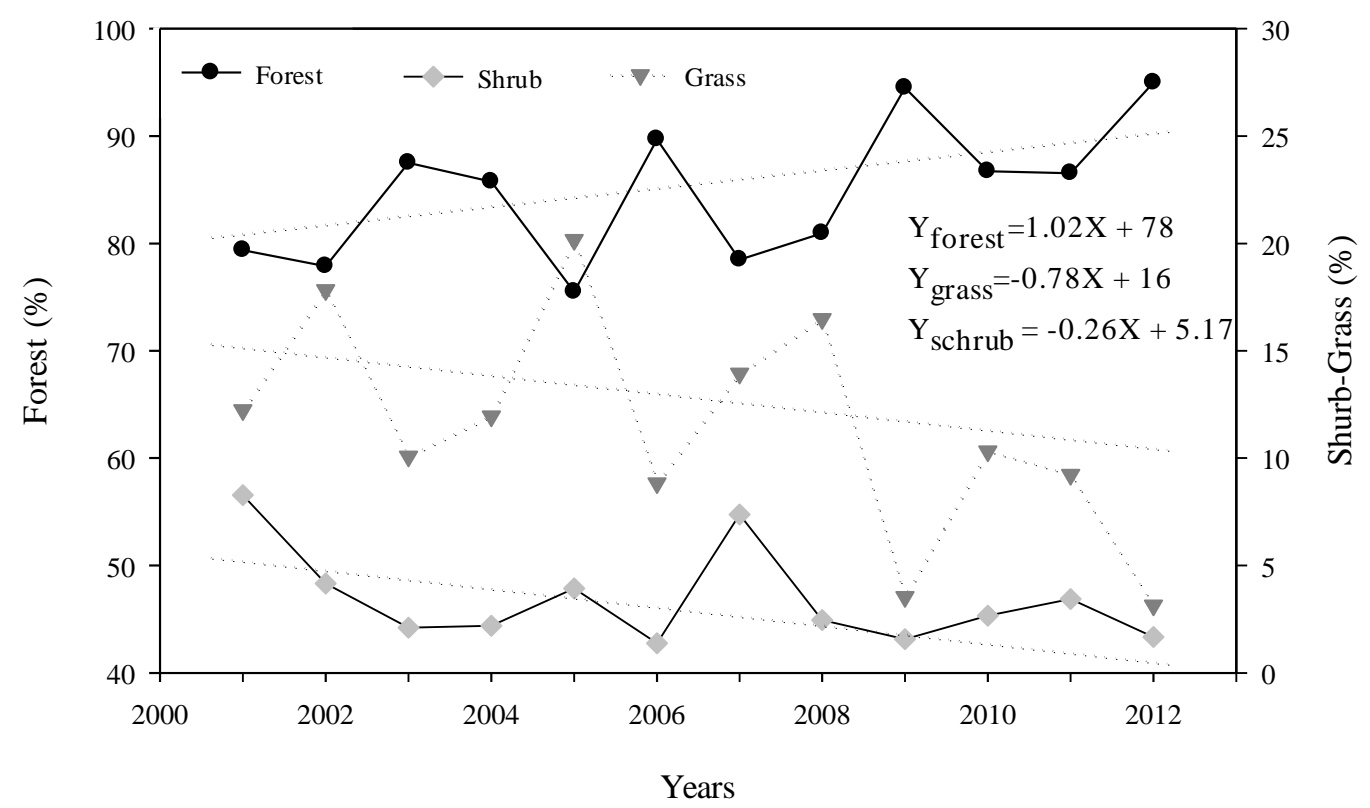

Fig. 4: Dynamics of the highest percentage classes of the conservation unit, Forest, Shrub and Grass.

When applying the linear regression technique to calculate the trend line, it was verified that the less vegetated classes (grass and shrub) in the period from 2001 to 2012 presented decrease and forest class, increment (Figure 4). The coefficient of determination $\left(\mathrm{R}^{2}\right)$ presented a value of approximately $30 \%$ for the grass class, $19 \%$ for the shrub class and 33\% for the forest class, expressing that these percentage values (attenuations and increase) are explained by the temporal variation in the RPPN SESC Pantanal (Figure 4). 


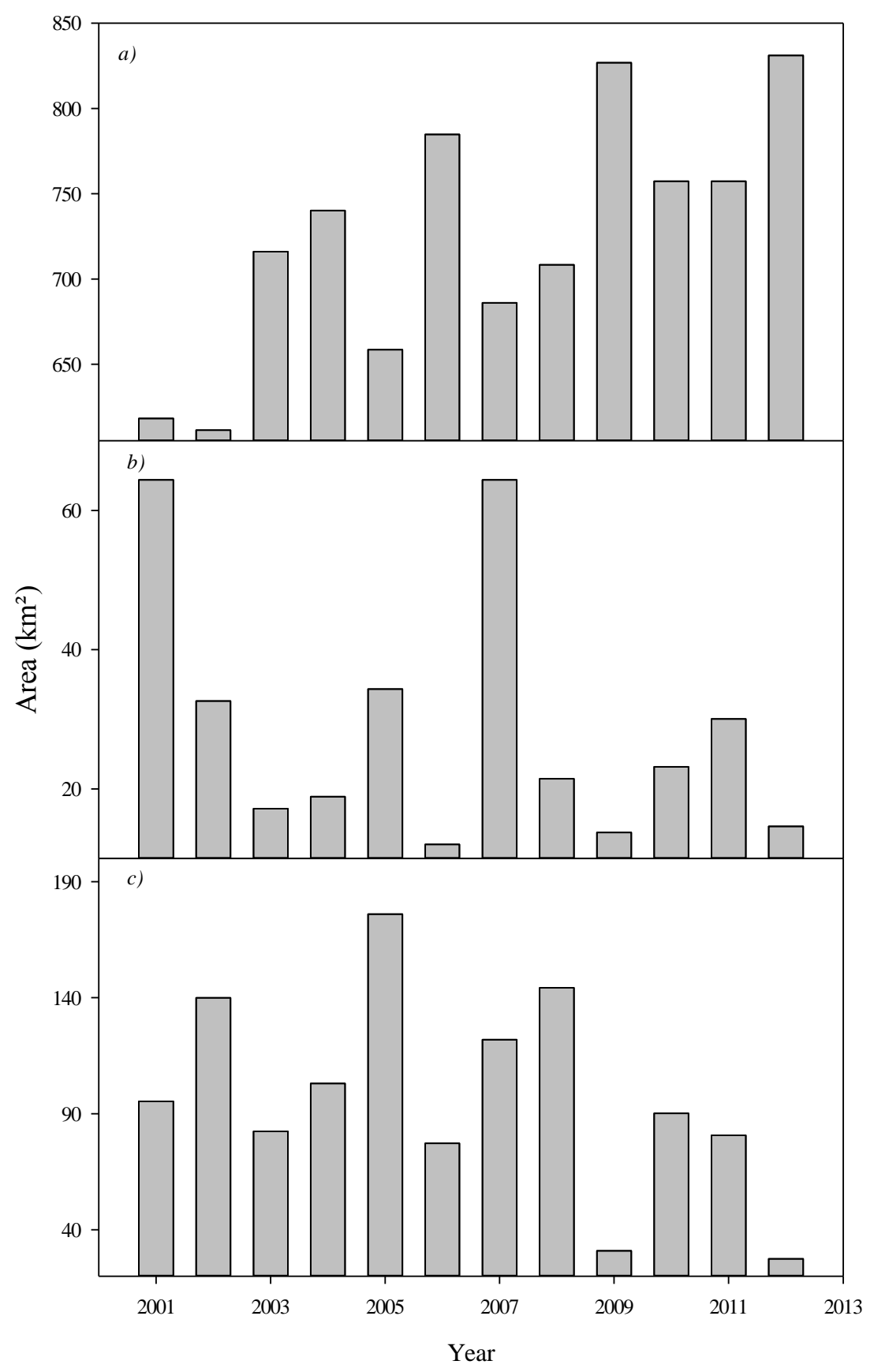

Fig. 5: Behavior for the most predominant classes in the reserve RPPN (a-forest, b-schrub and c-grass).

When applied to the Sturges formula (1926) for each MODIS product image (MCD12Q1), containing many 907 to 1019 pixels, the number of classes unanimously presented 11 (eleven) classes, for the 12 images (years of 2001 to 2012) corresponding to the total area of the RPPN SESC Pantanal (Table 2).

The class intervals amplitude was obtained by dividing the total amplitude of variation by the number of classes $(k)$, reaching an interval for each year, ranging from 37 to 50 pixels per image (Table 2). These class numbers agree, in just one more class, of that generated by the product algorithm MCD12Q1 (Table 2).

Studies involving a large amount of data such as orbital sensor images at long time intervals have achieved promising results using the Sturges rule for generation of numbers of vegetation classes and change of surface cover. García et al. (1998) evaluated a mangrove vegetation from 1970 to 1993 along the Santiago River, Mexico. By means of the Sturges rule applied to Landsat 5 satellite images and aerial photos, the authors obtained the distribution of the mangrove by different height classes. Hovestadt et al. (2005) studying the relation of plant species by areas with slope of land in a national park in Cote d'Ivoire, used the Sturges rule to aid in the classification of savanna and forest regions with Landsat satellite images, identifying 292 plant species throughout the study area. To understand the dynamics of deforested areas in the state of Roraima in the years 2000 to 2010 , Barni et al. (2015) used the Sturges rule applied to image classification of the Landsat 5 satellite, the authors concluded that the fires occurring in that region are associated with climatic events, areas with a drier climate and where open forests are concentrated. 
Table 2: Approximate determination of the number of classes of the RPPN SESC Pantanal by the Sturges' rule. Column contents: year, pixel numbers of the image that covers the entire RPPN, total number of classes to use $(K)$ and amplitude of the class interval.

\begin{tabular}{|c|c|c|c|}
\hline Year & Pixel numbers & K & Amplitude \\
\hline 2001 & 907 & 11 & 37 \\
\hline 2002 & 914 & 11 & 39 \\
\hline 2003 & 953 & 11 & 41 \\
\hline 2004 & 1005 & 11 & 46 \\
\hline 2005 & 1016 & 11 & 39 \\
\hline 2006 & 1019 & 11 & 43 \\
\hline 2007 & 1018 & 11 & 50 \\
\hline 2008 & 1019 & 11 & 41 \\
\hline 2009 & 983 & 11 & 45 \\
\hline 2010 & 1017 & 11 & 42 \\
\hline 2011 & 1019 & 11 & 48 \\
\hline 2012 & 1019 & 11 & 49 \\
\hline
\end{tabular}

When analyzing the difference in land use and occupation between 2001 and 2012, with emphasis on the classes with the highest occupancy in the RPPN SESC Pantanal (forest, shrub and grassland), it is observed that in the last year the forest class presents an increase higher than $15.6 \%\left(212.9 \mathrm{~km}^{2}\right)$ when compared to the first year. While the shrub and grass species classes decreased by approximately $6.6 \%$ and $9.1 \%\left(49.8\right.$ and $67.8 \mathrm{~km}^{2}$ ) (Figure 6 and 7). The expansion of the forest class is evident in the density at the center of the reserve, given by the circle overlapped in the scenes of 2001 and 2012 . These differences are equivalent to approximately $21,293.84$ ha of conversion from less vegetated classes to areas with predominance of forest in the reserve RPPN SESC Pantanal (Figure 6).

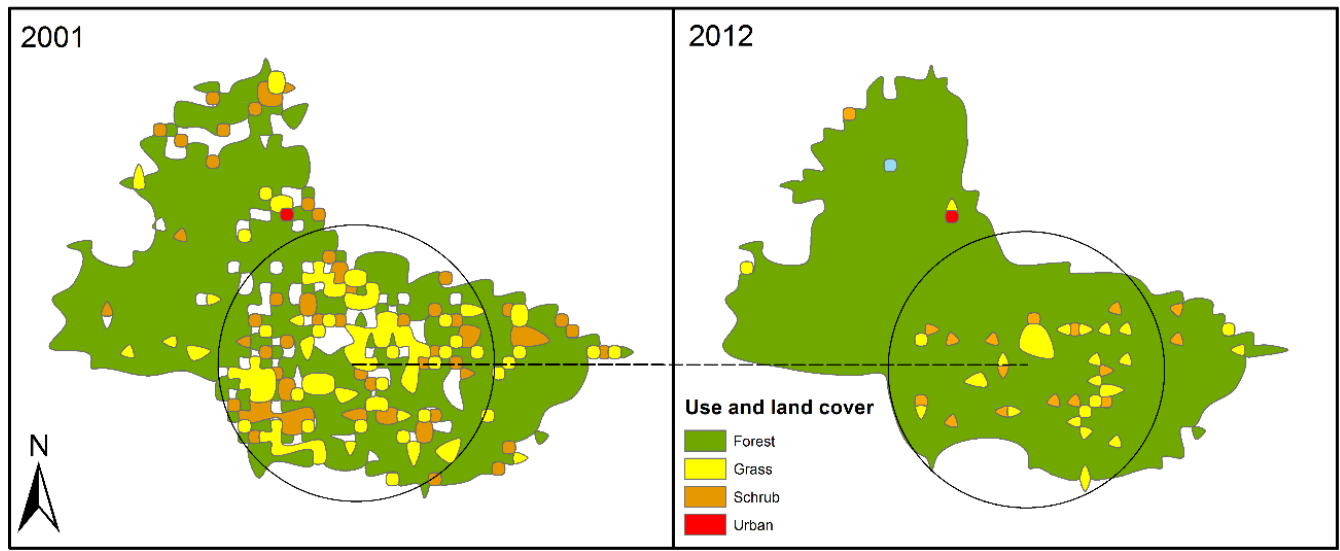

Fig. 6: Difference between the years 2001 and 2012.

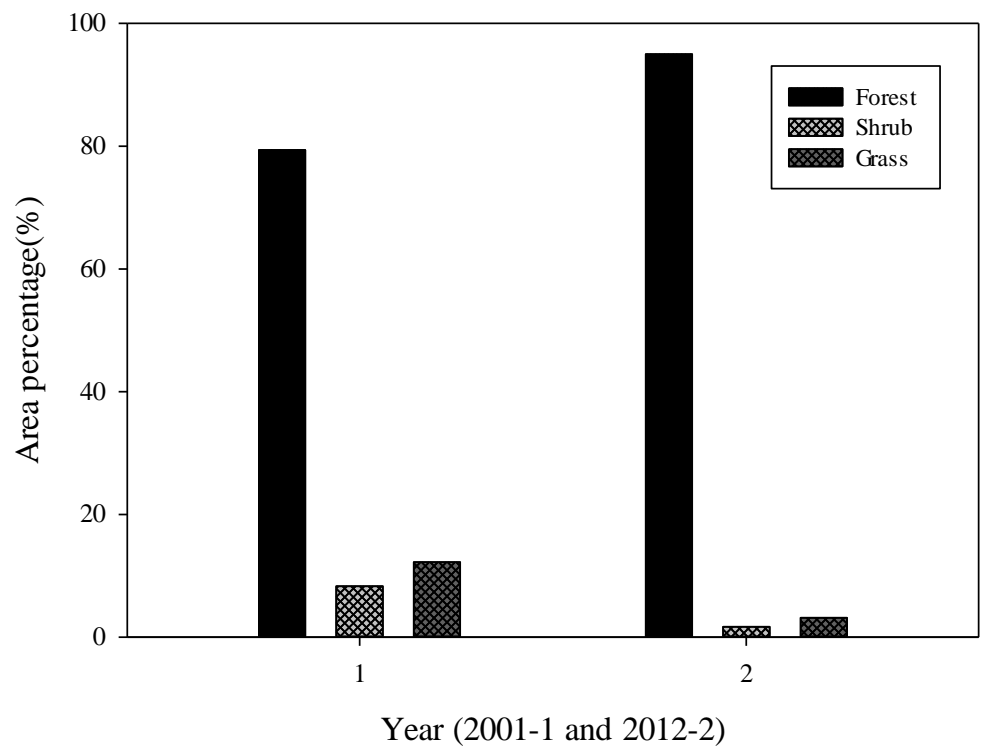

Fig. 7: Difference between the percentages of years 2001 and 2012 of land use and occupation in the RPPN SESC Pantanal. 
Citation: Victor Hugo de Morais Danelichen, et al., Assessment of Land Use in A Conservation Unit in the Brazilian Pantanal by Remote Sensing. Australian Journal of Basic and Applied Sciences, 13(6): 141-150. DOI: 10.22587/ajbas.2019.13.6.16

The land use and occupation classes of the RPPN SESC Pantanal varied in the twelve years analyzed, demonstrating a progressive increase in forest class and attenuation in less vegetated classes. It was verified that in the last year the forest class presented an increase of more than $15.6 \%$, as opposed to the shrub and grassy classes, which presented a decrease of $6.6 \%$ and $9.1 \%$.

The forest class presented an average of $85 \%$ occupancy of the total area of the reserve in relation to other classes, followed by $11.5 \%$ of the grass class and $3.4 \%$ of the shrub class, from 2001 to 2012.

In the last year analyzed, the forest class reached its maximum occupation of $95.0 \%$ of the entire area of the RPPN SESC Pantanal reserve, while the shrub and grassy classes presented occupancy of less than $4.0 \%$ for the same year.

The Sturges rule demonstrated agreement on the class numbers used by the MODIS sensor product. Our results also indicate that the MODIS MCD12Q1 sensor product is a useful tool and has been shown to evaluate the conservation effect of a large area reserve in the Mato Grosso Pantanal.

We also emphasize that the product MCD12Q1 can be used, except for some limitations in studies of the Pantanal biome, which are due to the use of classes of nomenclatures and ecosystems distinct from those that have been validated the product, its low spatial resolution restricting to studies of smaller areas in this biome.

\section{REFERENCES}

Abdon, M. M.; Silva, J. S. V.; Pott, V.J.; Pott, A.; Silva, M. P, 1998. Utilização de dados analógicos do LANDSAT-TM na discriminação da vegetação de parte da sub-região da Nhecolândia no Pantanal. Pesquisa Agropecuária Brasileira, Brasília, v.33, 1799-1813.

Andrade, R. M., Bolfe, E. L., Victoria, D. C., Nogueira, S. F, 2017. Avaliação das condições de Pastagens no Cerrado por meio de Geotecnologias. Revista Brasileira de Agropecuária Sustentável (RBAS), v.7, n.1, p.34-41, DOI number (DOI: 10.21206/rbas.v7i1.376).

Aquino, H. C., Galvanin, E. A. S., Neves, S. M. A., Lima, D, 2017. Análise da dinâmica de pastagem no Pantanal de Cáceres/MT. Geo UERJ, n. 30, p. 305-328, DOI number (doi: 10.12957/geouerj.2017.21490).

Barbosa, J. P. R. A. D.; Martins, G. A.; Ferreira, R. T.; Pennacchi, J. P.; Souza, V. F.; Soares, A. M, 2012. Estimativa do IAF de cafeeiro a partir do volume de folhas e arquitetura da planta. Coffee Science, Lavras, v. 7, n. 3, p. $267-274$.

Barni P.E.; Pereira V. B.; Manzi A. O.; Barbosa R.I, 2015. Deforestation and forest fires in Roraima and their relationship with phytoclimatic regions in the northern Brazilian Amazon. Environ Manage. 55(5), p.1124-38, DOI number (DOI: 10.1007/s00267-015-0447-7).

Brandão, L. G.; Antas, P. T. Z.; Oliveira, L. F. B.; Pádua, M. T. J.; Pereira, N. C.; Valutyk, W. W, 2011. Plano de manejo da Reserva Particular de Patrimônio Natural SESC Pantanal. Serviço Social do Comércio - SESC.

Biudes, M. S.; Nogueira, J. S.; Dalmagro, H. J.; Machado, N. G.; Danelichen, V. H. M.; Souza, M. C, 2012. Mudança no microclima provocada pela conversão de floresta de Cambará em pastagem no norte do Pantanal. Revista de Ciências AgroAmbientais, Alta Floresta-MT, v.10, n.1, p.61 - 68.

Cardoso, M. R. D.; Marcuzzo, F. F. N, 2010. Mapeamento de três decênios da precipitação pluviométrica |total e sazonal do bioma Pantanal. In: Anais.

Cordeiro, J. L. P.; Hasenack, H.; Oliveira, L. F. B, 2002. Estrutura e heterogeneidade da paisagem da estância ecológica do SESC Pantanal: evolução da paisagem na RPPN SESC/Pantanal. Barão de Melgaço, MT: terceiro relatório. Porto Alegre: Universidade Federal do Rio Grande do Sul, Instituto de Biociências, Centro de Ecologia, p.37.

Cordeiro, J. L. P. Estrutura e heterogeneidade da paisagem de uma unidade de conservação no nordeste do Pantanal (RPPN SESC Pantanal), Mato Grosso, Brasil: efeitos sobre a distribuição e densidade de antas (Tapirus terrestris) e de cervos-do-pantanal (Blastocerus dichotomus), 2004. Tese (Doutorado em Ecologia) - Programa de Pós-Graduação em Ecologia, Universidade Federal do Rio Grande do Sul, Porto Alegre.

Cunha, J.E. De B.L.; Rufino, I.A.A.; Silva, B.B. Da; Chaves, I. de B, 2012. Dinâmica da cobertura vegetal para a Bacia de São João do Rio do Peixe, PB, utilizando-se sensoriamento remoto. Revista Brasileira de Engenharia Agrícola e Ambiental, v.16, p.539-548. DOI number (http://dx.doi.org/10.1590/S1415-43662012000500010).

Danelichen, V. H. M., Biudes, M. S.; Souza, M. C., Machado N. G., Nogueira, J. S., 2016. Relations of vegetation and water indices to volumetric soil water content in the Pantanal of Mato Grosso, Brazil. Journal International Journal of Remote Sensing, v. 37, n.18, p. 4261-4275, DOI number (http://dx.doi.org/10.1080/01431161.2016.1213921).

Fantin-Cruz, I.; Girard, P.; Zeilhofer, P.; Collischonn, W.; Nunes Da Cunha, C, 2010. Unidades fitofisionômicas em mesoescala no Pantanal Norte e suas relações com a geomorfologia. Biota Neotropica, n. 10, v. 2, p. 31-38, DOI number (http://dx.doi.org/10.1590/S1676-06032010000200002).

Feilhauer, H. \& Schmidtlein, S, 2009. Mapping continuous fields of forest alpha and beta diversity. Applied Vegetation Science, v.12, n.4, p.429-439, DOI number (https://doi.org/10.1111/j.1654-109X.2009.01037.x).

García, P. R.; Blanco, J. P.; Ocaña, D, 1998. Mangrove vegetation assessment in the Santiago River Mouth, Mexico, by means of supervised classification using Landsat TM imagery. Forest Ecology and Management, 105. p.217-229, DOI number (DOI: 10.1016/S0378-1127(97)00289-2).

Gurgel, H.; Hargrave, J; França, F.; Holmes, R. M.; Ricarte, F. M.; Dias, B. F. S.; Rodrigues, C. G. O.; Brito, M. C. W, 2009. Unidades de conservação e o falso dilema entre conservação e desenvolvimento. Boletim Regional, Urbano e Ambiental, n 3, p.109-120.

Hofmann, G. S.; Hasenack, H.; Oliveira, L. F. B.; Cordeiro, J. L. P, 2010. O clima na Reserva Particular do Patrimônio Natural SESC Pantanal. Serviço Social do Comércio - SESC. 
Citation: Victor Hugo de Morais Danelichen, et al., Assessment of Land Use in A Conservation Unit in the Brazilian Pantanal by Remote Sensing. Australian Journal of Basic and Applied Sciences, 13(6): 141-150. DOI: 10.22587/ajbas.2019.13.6.16

Hovestadt, T.; Joachim Poethke, H.; Eduard Linsenmair, K, 2005. Spatial patterns in species-área relationships and species distribution in a West African forest-savanna mosaic. Journal of Biogeography, v. 32, p. 677-684, DOI number (DOI: 10.1111/j.1365-2699.2004.01192.x).

INPE/CPTEC. 2009. Condições climáticas observadas no brasil em 2009. Boletins climáticos.

Jiang, Y., De Bie, C.A.J.M., Wang, T., Skidmore, A.K., Liu, X., Song, S. \& Shao, X, 2013. Hyper-temporal remote sensing helps in relating epiphyllous liverworts and evergreen forests. Journal of Vegetation Science, v.24, p.214-226, DOI number (https://doi.org/10.1111/j.1654-1103.2012.01453.x).

Leite, M. R.; Brito, J. L. S, 2012. Avaliação de desempenho entre modelos de obtenção de temperatura de superfície por sensores remotos. OBSERVATORIUM: Revista Eletrônica de Geografia, v.4, n.12, p. 73-89.

Machado, N.G., Sanches, L., Silva, L.B., Novais, J.W.Z., Aquino, A.M., Biudes, M.S., Pinto-Junior, O.B., Nogueira, J.S, 2015. Soil nutrients and vegetation structurein a neotropical seasonal wetland. Applied Ecology Environmental Research, v.13, n.2, p.289-305, DOI number (10.15666/aeer/1302_289305).

Melo, M. L, 2000. Impacto do fenômeno El Niño sobre a região centro-oeste do Brasil. In: CONGRESSO BRASILEIRO DE METEOROLOGIA. Anais (CD-ROM), 11, Rio de Janeiro.

Mendonça, F. A., Buffon, E. A, 2019. Aplicação da Escala Temporo-Espacial Fina em estudo de Inundações Urbanas: Painéis Para Curitiba-Pr, Brasil. Geo UERJ, Rio de Janeiro, n. 34, p.1-19, DOI number (DOI: https://doi.org/10.12957/geouerj.2019.40943).

Miranda, M. R. S., Luz, C. C. S., Neves, S. M. A. S., Scheuer, J. M, 2018. Cobertura vegetal e uso da terra no Assentamento Paiol-Brasil: Subsídios Para a Conservação do Pantanal. Revista de Geografia - PPGEO - UFJF. v.8, n.1, p.59-68.

Novais J. W. Z., Sanches L., Silva L. B., Machado N. G., Aquino A. M., Pinto Junior O. B., 2016. Albedo do solo abaixo do dossel em área de Vochysia Divergens Pohl no norte do Pantanal. Revista Brasileira de Meteorologia, 31(2): 157-166. (DOI: http://dx.doi.org/10.1590/0102-778631220150001).

Novais, J. W. Z.; Sanches, L.; Dias, V. M., Machado, N. G.; Silva, L. B.; Aquino, A. M. Variação espaço-temporal da PAR refletida pelo solo e transmitida pelo dossel em floresta inundável no pantanal mato-grossense. Ciência Florestal, Santa Maria, v. 28, n. 4, p. 1502-1513, 2018. (DOI: http://dx.doi.org/10.5902/1980509835097).

Nunes da Cunha, C. \& Junk, W.J, 2004. Year-to-year changes in water level drive the invasion of Vochysia divergens in Pantanal grasslands. Applied Vegetation Science, v.7, p.103-110, DOI number (https://doi.org/10.1111/j.1654-109X.2004.tb00600.x).

Oliveira, L. M. M.; Montenegro, S. M. G. L.; Antonio, C. D. A.; Silva, B. B.; Machado, C. C. C.; Galvíncio, J. D, 2012. Análise quantitativa de parâmetros biofísicos de bacia hidrográfica obtidos por sensoriamento remoto. Pesquisa Agropecuária Brasileira, Brasília, v.47, n.9, p.1209-1217. DOI number (http://dx.doi.org/10.1590/S0100-204X2012000900005).

Oliveira, N, L.; Marcuzzo, F. F.; Barros, R. G, 2015. Influência do El Niño e La Niña no número de dias de precipitação pluviométrica no Estado do Mato Grosso. Ciência e Natura, Santa Maria, v. 37, n. 4, p. 284-297, DOI number (DOI: http://dx.doi.org/105902/2179460X12717).

Peres, P. N.; Mioto, C. L.; Marcato Junior, J.; Paranhos Filho, A. C, 2016. Variação da Cobertura do Solo no Pantanal de 2000 a 2015 por Sensoriamento Remoto com Software e Dados Gratuitos. Anuário do Instituto de Geociências - UFRJ, v. 39 - 2 / 2016 p. 116-123.

Ramos, H. C.; Dallacort, R.; Santi, A.; Seabra Junior, S.; Queiroz, T. M, 2015. Precipitação pluvial de Diamantino-MT em anos de ocorrência de El niño, La niña e Neutros. Revista Brasileira de Meteorologia, v. 30, n. 1, p. 71-80, DOI number (ttp://dx.doi.org/10.1590/0102-778620120477).

Ravaglia, A. G.; Santos, S. A.; Soriano, B. M. A.; Daniel, O.; Freitas, L. C.; Pellegrin, L. A.; Tomas, W. M.; Rodela, L. G.; Sobrinho, A. A. B.; Araujo, M. T. B, 2011. Mapeamento das Unidades de Paisagem das Subregiões da Nhecolândia e Poconé, Pantanal Mato-Grossense. Boletim de Pesquisa e Desenvolvimento 105, Embrapa, ISSN 1981-7215.

Rodela, L. G.; Queiroz Neto, J. P.; Santos, S, 2007. A Classificação das pastagens nativas do Pantanal da Nhecolândia, Mato Grosso do Sul, por meio de imagens de satélite. In: SIMPÓSIO BRASILEIRO DE SENSORIAMENTO REMOTO. Florianópolis, 13, 2007, Florianópolis. Anais, São José dos Campos: INPE, p. 4187-4184.

Rocchini, D. \& Neteler, M, 2012. Let the four freedoms paradigm apply to ecology. Trends in Ecology and Evolution, v.27, p.310-311, DOI number (DOI: 10.1016/j.tree.2012.03.009).

Rocchini, D, 2013. Seeing the unseen by remote sensing: satellite imagery applied to species distribution modeling. Journal of Vegetation Science, v.24, p.209-210. DOI number (https://doi.org/10.1111/jvs.12029).

Senna, M.C.A., Costa, M.H., Shimabukuro, Y.E. Avaliação do produto FPAR para a floresta tropical amazônica, in: Rudorff, B.F.T., Shimabukuro, Y.E., Ceballos, J.C, 2007. O sensor MODIS e suas aplicações ambientais no Brasil. Editora Parêntese, São José dos Campos, pp. 237-251.

Silva Mp, Mauro Ra, Mourão G, Coutinho M, 2000. Distribuição e quantificação de classes de vegetação do Pantanal através de levantamento aéreo. Rev Bras Bot 23(2): 143-152, DOI number (http://dx.doi.org/10.1590/S0100-84042000000200004).

Sturges, H. A, 1926. The choice of a class interval. Journal of the American Statistical Association, New York, v. 21, n. 153, p. 65-66, DOI number (https://doi.org/10.1080/01621459.1926.10502161).

Vigano, H. H. G., Souza, C. C., Cristaldo, M. F., Neto, J. R. N., Jesus, L, 2018. Incêndios no Pantanal de Corumbá, MS: modelagem e previsão a partir das técnicas de análise multivariada. Rev. Ambient. Água. v.13, n.5, p.1-13, DOI number (http://dx.doi.org/10.4136/ambi-agua.2024). 